\title{
The Effect of Participative Leadership , Team Work, Stress Management on Teacher's Affective Commitment at Senior High School
}

\author{
Elprida Sulastri Lumbantoruan \\ Educational Administration \\ Department \\ Postgraduate, State University of \\ Medan \\ Medan, Indonesia \\ elpridalumbantoruans@gmail.com
}

\author{
Sukarman Purba \\ Lecturer of State University of Medan \\ Medan, Indonesia
}

\author{
Eka Daryanto \\ Lecturer of State University of Medan \\ Medan, Indonesia
}

\begin{abstract}
The objective of this study to analyze the effect of: Partisipatif Leadership on Stress Management, Teamwork on Stress Management, Partisipatif Leadership on Teachers Affective Commitment,Teamwork on Teachers Affective Commitment and Stress Management on Teachers Affective Commitment. This research was conducted at the Senior High School and the total population was 265 teachers. The number of samples using Slovin Formula as 159 teachers, with is used Proportional Random Sampling. Data collecting by questionnaire. Instruments for testing Validity and Reliability test. To test the research hypothesis, path analysis was used. The results showed that Partisipatif Leadership had a direct positive effect on Stress Management, Teamwork had a direct positive effect on Stress Management, Partisipatif Leadership had a direct positive effect on Teachers Affective Commitment, Teamwork had a direct positive effect on Teachers Affective Commitment and Stress Management had a direct positive effect on Teachers Affective Commitment. To improve Teachers Affective Commitment can be done by increasing Partisipatif Leadership, Teamwork, and Stress Management.
\end{abstract}

Keywords- Participative Leadership, Teamwork, Stress Management on Teachers Affective Commitment

\section{INTRODUCTION}

Education held important things to develop a country because the aim of national education is to enrich the religious ,kind, high intellectual, responsible, dependent and capable in science and technology. This is related to the Industry 4,0 where : (1) Students must be capable to create job ; (2) Students must be capable to solve the problem ; (3) Students must be capable in science and technology. The report of interview a headmaster of SMA N.2 Parmonangan said that : Teachers Commitment is poor , (1) Teacher has other job which will be his/her priority; (2) Teacher is not proud to be Organization member because they is seldom to follow the meeting or self improvement namely MGMP ; (3)responsible is low because they can leave the task when Teaching -Learning Process is going on; (4) Teacher is not seriously to give their best ; (5) Teacher is not proud to be a professional teacher.

Silitonga stated that teacher commitment especially affective commitment is $60 \%$.It can be support with the percentage of teacher absence as follow :

TABLE 1. TEACHER ATTENDANCE PERCENTAGE

\begin{tabular}{|l|l|l|}
\hline No & Year & Percentage \\
\hline 1 & 2016 & $99,09 \%$ \\
\hline 2 & 2017 & $99,10 \%$ \\
\hline 3 & 2018 & $99,20 \%$ \\
\hline
\end{tabular}

source :Kantor Cabang Dinas Pendidikan

Shirley stated that high or low affective commitment to get the goal is the Organizational Commitment problem especially Affective Commitment[1]. The teachers in SMA N.2 Parmonangan said that they will be motivated to teach if the student $\mathrm{s}$ in Teaching - Learning Process can be motivated. And if they cannot find in class they will be influenced.

Based on the opinion above, Olivia stated that there is a correlation within Participative Leadership, Teamwork and Stress Management to encourage teacher affective commitment.

Some researchers that analyze this research namely : (1) Ramli about participative leadership influenced affective commitment[2] ; (2)Christin about teamwork to encourage teachers affective commitment[3]; (3) Ahmad about stress management stated that teacher perception about principle leadership ,motivation, and stress management towards teacher affective commitment[4].

Based on the above opinion, the researcher want to analyze the influence of participative leadership ,teamwork ,and stress management in order to encourage affective commitment on teachers at SMA entitled : The Effect of Participative Leadership, Teamwork,Stress Management on Teachers's Affective Commitment at Senior High School 


\section{LITERATURE REVIEW}

\section{Affective Commitment}

Kreitnerdan Kinickistated commitment come from "commitere", to connect, entrust the state of being obligated or emotionally impelled [5].Colquit, Lepine and Wesson stated some factors as commitment factors such as culture organization,Leadership Styles and Behavior such as Partisipatif Leadership Style, Personality and Cultural Values, Teamwork,Stress Management, and Motivation[6]

Allan and Meyer classified organizational Commitment would be three parts such as :

1. Affective Commitment : the employee's emotional attachment to, indentification with, and involvement in the organization

2. Continuance Commitment : an awareness of the cost associated with leaving the organization

3. Normative Commitment : a feeling of obligation to continue employment [7]

Affective Commitment Definition

$>$ According to Schuluz and Schuluz,affective Commmitment or attidutional Commmitment is a condition where individu consider what is his aim and value is related to organization purpose and values [8]

$>$ According to Wibowo : An interested pschicologist into organization to be stay and has emotional relationship into organization [9]

$>$ According to Meyer and Herscovitch : An interested emotional to the organizational and also there is a positive correlation where as higher affective commitment as higher achievement and can be reward from organization to the employee such as promotion or reward[7]

As a conclusion Affective Commitment is a will or capable for each employee (teacher) to do their job and obedience as a teacher, innovative and responsive to follow the Science and Technology improvement with indicator such as : (1) loyal; (2) be a proud to the organization; (3) active to improve organization; (4) believe that the organization is the best; (5) has a close relationship to organizational emotionally.

\section{Participative Leadership}

Kreitner and Kinicki stated that leadership is a social influence where a leader try to take dvoulunteer partisipatif from the employee to work in order to reach the purpose or the goal of the organization[5]

Thoa classified that leadership styles such as :

1. Instruction : The Leader behavior where it is high instruction and low support
2. Consultative : The Leader behavior where there is balance communication between instruction and support

3. Partisipatif : The leader behavior where it is low instruction and high support or partisipatif employee[10]

Participatif Leadership definition :

$>$ Yukl said that it is a leadership which is power sharing and empowering is given to all the member or employee [11]

$>$ Leithword said that it is a leadership which is the decision is determined by the employee [2]

$>$ Crimmon said that it is a leadership which is controlling, problem solving and decision is hold by the employee [2]

$>$ Sergiovani and Savery said it is a leadership wherethe decision is focused to the partisipatif needed of employee so they will motivate to work[2]

$>$ Usman said that it is a leadership which will give power and decision taking to the employee in order to motivate them[12]

As a conclusion, participative leadership is a behaviour leader which take partisipatif opinion and consider their needy in order to take decision or a wise by indicator such as : (1) Sharing to take a decision ; (2) justice attitude to all employee ; (3) The common interest priority ; (4) The finishing of the job description is on the time will be priority; (5)encourage the employee to be obedience into the rules.

\section{Teamwork}

$>$ Leonard said that teamwork is a leadership where all members is cooperative in problem solving and the goa achievement in organization[2].

$>$ Gregory said that teamwork is the capable of organization members to share job and communicate effectively, take and give each members needy, trusting and doing different job which is coordinate [2].

$>$ Lehner said that teamwork is the activity where is cooperative in order to take a common goal in different knowledgse and skills [2].

$>$ Colquit, Lepine and Wesson said that teamwork is a team consists of two or more personal which work independently for a while in order to take a common goal which is task - oriented purpose [5]

$>$ Daft said that teamwork is there are two or more person which is share job and coordinate in finishing a specific task [13] 
We can conclude that teamwork is a coordination and sharing job and responsible in order to take a common goal by indicators such as : (1) every members is owned each other ; (2)enrich spirit of team work ; (3) there is a feedback one to others; (4) trusting each other ; (5) have a common goal ; (6) independently

\section{Stres Management}

$>$ Chermis said thatstress is the situation where a demands is more complex if we compare with human capable [3]

$>$ Colquit, Le Pine and Wesson said that stress is psychologist respond to face the demands which is not balanced with the personal capable[6]

$>$ Gibson said that stress is an addictive responsive which is mediated by individual characteristic or psychology process which will be founded from the attitude ,situation, and events in their circumstances which causes the excessive psychology and physic needy to someone [14]

$>$ Luthans said that stress isindividual interaction with their circumstance, where individual responsive which is mediated by different individual or psychology process as a result of external situation and effect [15]

$>$ Dampsey said that an imbalance within personality characteristic with job description demands and it will be founded for every kinds of job normally.

Stress management is human ability effectively to face a disturbing and an emotional psychologically as a feedback or responsive [3]

As a conclusion, stress management is an ability of human to manage pressure from internal or external himself have positive influence for work commitment by indicator : (1) Time Management efficiently and effectively ; (2) Sport Exercise ; (3)Refreshing Day ; (4) Social Activity such Tour Program.

\section{METHOD}

This research uses a quantitative approach, namely research used to examine populations and certain samples and use data collection with research instruments that aim to test the hypotheses that have been set. this research was carried out in SMA in August 2019 to September 2019 for two month. The population in this study were all 265 of teachers in SMAwith a total sample of 159 respondents.

\section{RESULT AND DISCUSSION}

\section{The Effect of Participative Leadership (X1) on Stress Management (X3)}

Based on the results of the study, Participative Leadership (X1) has a positive direct effect on the Stress Management of SMAteachers . From the calculation results obtained by the path coefficient of the influence of the Participative Leadership (X1) on Stress Management $(\mathrm{X} 3)=$ $\rho_{31}=0.308$ with a coefficient value of $t=4.669$ and with a significance of $\mathrm{p}=0.000$ or a $\mathrm{t}$-value greater than the value of $\mathrm{t}$ table $\alpha(0.05)=1,960$ so that $\mathrm{Ho}$ is rejected and $\mathrm{Ha}$ is accepted. Thus, it can be concluded that Participative Leadership has a direct positive effect on the teacher's Stress Management of SMA. So that means, the higher the Participative Leadership of each teacher in the school, the better the teacher's Stress Management. In other words, the pros and cons of Stress Management of SMA teacher's are very much determined by the level of Participative Leadership of each teacher in the school.

\section{The Effect of Teamwork(X2) on Stress Management (X3)}

Based on the results of the study, the Teamwork(X2) has a positive direct effect on teacher's Stress Management(X3) of SMA Negeri From the calculation results obtained by the path coefficient value of the influence of the Teamwork on Stress Managementat $\rho_{32}=0.457$ with a coefficient value of tcount $=$ 6,935 and the significance of 0.001 or $t$ value is greater than the value of the table $\alpha(0.05)=1,960$ so that Ho is rejected and $\mathrm{Ha}$ is accepted. Thus, it can be concluded that the Teamwork has a direct positive effect on the teacher's Stress Management of SMA . Then it means, the better the Teacher's Teamwork, the higher the Stress Management of the teacher. In other words, the level of teacher's Stress Management of SMA is largely determined by the pros and cons of the teacher's Teamwork.

\section{Effect of Participative Leadership (X1) on Affective Commitments (X4)}

Based on the results of the study, Participative Leadership (X1) has a positive direct effect on teacher's Affective Commitments (X4) of SMA . From the calculation results obtained by path analysis the path coefficient value of the influence of the Participative Leadership on Affective Commitment at $\rho_{41}=0.344$ with a coefficient value of $\mathrm{t}=$ 6.001 and a significance of 0.000 or a value of tcount greater than the value of the table $\alpha(0.05)=1.960$ so Ho is rejected and $\mathrm{Ha}$ accepted. Thus, it can be concluded that the Participative Leadership has a direct positive effect on the teacher's Affective Commitment of SMA So that means, the higher the Participative Leadership of each teacher in the school, the higher the Teacher's Affective Commitment. In other words, the level of teacher's affective commitment of 
SMA is very much determined by the level of Participative Leadership of each teacher in the school.

\section{Effect of Teamwork (X2) on Affective Commitments (X4)}

Based on the results of the study, the Teamwork (X2) has a positive direct effect on teacher's Affective Commitment (X4) of SMA . From the calculation results obtained by the path analysis shows that the path coefficient value of the influence of the Teamwork on Affective Commitment at $\rho_{42}=0.264$ with a coefficient value of $t=4,297$ and the significance of 0.000 or tvalue is greater than the value of the table $\alpha(0.05)=1.960$ so Ho rejected and Ha accepted. Thus, it can be concluded that the Teamwork has a positive direct effect on the teacher's Affective Commitment of SMA. So that means, the better the Teacher's Teamwork, the higher the Teacher's Affective Commitment. In other words, the level of teacher's affective commitment is highly determined by the pros and cons of the teacher's teamwork.

\section{Effect of Stress Management (X3) on Affective Commitments (X4)}

Based on the results of the study, Stress Management (X3) has a positive direct effect on teacher's Affective Commitment (X4) of SMA From the calculation results obtained by path analysis the path coefficient value of the influence of Stress Management on Affective Commitment at $\rho_{43}=0.398$ with a coefficient value of tcount $=6,107$ and the significance of 0.000 or tvalue is greater than the value of the table $\alpha(0.05)=$ 1.960 so $\mathrm{Ho}$ is rejected and $\mathrm{Ha}$ accepted. Thus, it can be concluded that Stress Management has a direct positive effect on the teacher's Affective Commitment of SMA. So that means, the better the teacher's stress management , the higher the teacher's affective commitment. In other words, the level of teacher's affective commitment of SMA is highly determined by the pros and cons of teacher's stress management.

\section{CONCLUSION}

1. Participative Leadership has a direct positive effect on the teacher 's Stress Management teacher's of SMA.

2. Teamwork has a positive direct effect on the the teacher 's Stress Management teacher's of SMA.

3. Participative Leadership has a positive direct effect on the teacher's Affective Commitment of SMA

4. Teamworkhas a positive direct effect on the teacher's Affective Commitment of SMA.

5. Stress Management has a direct positive effect on the teacher's Affective Commitment of SMA

\section{ACKNOWLEDGMENT}

The author hereby showed her gratitude to their supervisors in State University of Medan, Dr. Sukarman Purba, M.Pd, and
Dr. Eka Daryanto, MT for their sincere guidance and motivation during the research process.

\section{REFERENCES}

[1] Shirley Sidabutar, Paningkat Siburian\& Salman Bintang.2017 "Pengaruh Budaya Organisasi, kepuasan Kerja, Dan Motivasi Berprestasi Terhadap Komitmen Organisasi Guru SMP Negeri Kecamatan Simanindo dan Kecamatan Pangururan Kabupaten Samosir Jurnal Manajemen Pendidikan Indonesia.Vol.9 N0.2.62-73

[2] Ramli.2015 " Pengaruh Persepsi Guru Tentang Kepemimpinan Partisipatif Kepala Sekolah Dan Motivasi Kerja Terhadap Komitmen Afektif Guru Di SMA YAPIM Taruna Se- Kabupaten Deli Serdang": Medan ,Universitas Negeri Medan (Unpublished)

[3] Christin.2018 "Pengaruh Disiplin Kerja ,Kecerdasan Spritual, Dan Kerjasama Tim Terhadap Komitmen Kerja Guru di SD Negeri Kecamatan Selesai Kabupaten Langkat ; Universitas Negeri Medan (Unpublished)

[4] Ahmad..2017 “ Pengaruh Budaya Organisasi ,Motivasi Kerja ,Dan Pengelolaan Stres Terhadap Komitmen Afektif Guru SMP Negeri Di Kecamatan Gunung Mariah Kabupaten Aceh Singkil : Universitas Negeri Medan (Unpublished)

[5] Kreitner, Robert \& Angelo Konicky,2005 “ Perilaku Organisasi. Jakarta “: Salemba Empat

[6] Colquit, JasonA, Jeffery Ale Pine, dan Michael J.Wasson.2009“ Organizational Behaviour Improving and Commitment in the Workplace New York : McGraw- Hill

[7] Meyer,J.P \& Herscovitch, L,2008 “ Commitment in the workplace toward a general model Human resource management review "

[8] Schultz, D.\& Schultz, E.S.2002 “ Theories of Personality ( $\left.5^{\text {th }}\right)$ California " : Brooks/ Cole Publishing Company

[9] Wibowo.2004 " Manajemen Kinerja. Jakarta ": Raja Grafindo Persada

[10] Thoha ,Miftah.2007 “ Kepemimpinan Dalam Manajemen. Jakarta “ : Raja Grafindo Persada

[11] Yukl,G.2007 “ Kepemimpinan Dalam Organisasi. Alih Bahasa “ : Yusuf Udaya.Jakarta; Prehallindos

[12] Usman, Moh.Uzer.2002 “ Menjadi Guru Professional.Bandung “ : Remaja Rosdakarya

[13] Daft, Richard L.2005" The Leadership Experience "South Western : Vanderbilt University

[14] Gibson, 2009 “ Organisasi Perilaku Struktur Proses. Alih Bahasa “: Djarkasih. Jakarta: Erlangga

[15] Luthans, F.1988 " Perilaku Organisasi. Terjemahan " : Vivin Andika Yuodo : Sekar Purwati. Yogyakarta : Andi

[16] Arikunto, Suharsimi2006 "Prosedur Penelitian, Suatu Pendekatan Praktis". Jakarta: Rineka Cipta

[17] Fattah , Nanang.2004 “ Landasan Manajemen Pendidikan “ Bandung : Remaja Rosdakarya

[18] Kreitner ,R.Kinicki,A.\&Irwin.2003 “Organizational Behavioral (third edition) “"

[19] Mowday, Porter \& Steers. 1992 “ Employee Organizational Linkages: The Psychology of Commitment, Absenteeism and Tumove New York ": Academic Press 